\title{
Quantification of topographic venting of boundary layer air to the free troposphere
}

\author{
S. Henne ${ }^{1}$, M. Furger ${ }^{1}$, S. Nyeki ${ }^{1,2}$, M. Steinbacher ${ }^{1}$, B. Neininger ${ }^{3}$, S. F. J. de Wekker ${ }^{1, \star}$, J. Dommen ${ }^{1}$, \\ N. Spichtinger ${ }^{4}$, A. Stohl ${ }^{4}{ }^{\dagger}$, and A. S. H. Prévôt ${ }^{1}$ \\ ${ }^{1}$ Paul Scherrer Institut, Villigen, Switzerland \\ ${ }^{2}$ University of Essex, Colchester Essex, UK \\ ${ }^{3}$ MetAir AG, Illnau, Switzerland \\ ${ }^{4}$ Lehrstuhl für Bioklimatologie und Immissionsforschung, Technical University of Munich, Freising, Germany \\ ${ }^{\star}$ Current affiliation: Pacific Northwest National Laboratory, Richland, Washington, USA \\ ${ }^{\dagger}$ Current affiliation: University of Colorado/NOAA Aeronomy Laboratory, Boulder, CO, USA
}

Received: 21 August 2003 - Published in Atmos. Chem. Phys. Discuss.: 16 October 2003

Revised: 10 February 2004 - Accepted: 10 March 2004 - Published: 24 March 2004

\begin{abstract}
Net vertical air mass export by thermally driven flows from the atmospheric boundary layer (ABL) to the free troposphere (FT) above deep Alpine valleys was investigated. The vertical export of pollutants above mountainous terrain is presently poorly represented in global chemistry transport models (GCTMs) and needs to be quantified. Air mass budgets were calculated using aircraft observations obtained in deep Alpine valleys. The results show that on average 3 times the valley air mass is exported vertically per day under fair weather conditions. During daytime the type of valleys investigated in this study can act as an efficient "air pump" that transports pollutants upward. The slope wind system within the valley plays an important role in redistributing pollutants. Nitrogen oxide emissions in mountainous regions are efficiently injected into the FT. This could enhance their ozone $\left(\mathrm{O}_{3}\right)$ production efficiency and thus influences tropospheric pollution budgets. Once lifted to the FT above the Alps pollutants are transported horizontally by the synoptic flow and are subject to European pollution export. Forward trajectory studies show that under fair weather conditions two major pathways for air masses above the Alps dominate. Air masses moving north are mixed throughout the whole tropospheric column and further transported eastward towards Asia. Air masses moving south descend within the subtropical high pressure system above the Mediterranean.
\end{abstract}

Correspondence to: A. S. H. Prévôt

(andre.prevot@psi.ch)

\section{Introduction}

Nitrogen oxides $\left(\mathrm{NO}_{\mathrm{x}}=\mathrm{NO}_{2}+\mathrm{NO}\right)$ and volatile organic compounds (VOC) govern $\mathrm{O}_{3}$ production in the troposphere (Seinfeld and Pandis, 1998). Most anthropogenic and biogenic emissions of $\mathrm{NO}_{\mathrm{x}}$ and VOCs take place in the ABL. The $\mathrm{O}_{3}$ production efficiency, which is the number of $\mathrm{O}_{3}$ molecules produced by each $\mathrm{NO}_{\mathrm{x}}$ molecule consumed (Lin et al., 1988), is enhanced by transport to the FT (Seinfeld and Pandis, 1998). Once the air mass has left the ABL, dry deposition of $\mathrm{NO}_{\mathrm{x}}$ and $\mathrm{O}_{3}$ ceases and leads to an increased lifetime of these species. As temperatures decrease in the troposphere with increasing altitude the reaction of $\mathrm{NO}$ with $\mathrm{O}_{3}$ is decelerated. Therefore the photostationary state of the $\mathrm{O}_{3}-\mathrm{NO}_{\mathrm{x}}$ cycle is shifted to a higher $\mathrm{NO} / \mathrm{NO}_{2}$ ratio. In addition peroxyacetyl nitrate (PAN) can act as a reservoir species for $\mathrm{NO}_{2}$ at lower temperatures. The lower the concentration of $\mathrm{NO}_{2}$ the more $\mathrm{OH}$ radicals react with hydrocarbons and therefore enhance $\mathrm{O}_{3}$ production (as long as $\mathrm{NO}>10-30$ pptv). Mixing ABL air with FT air, which contains considerable background concentrations of methane and carbon monoxide, leads to a higher hydrocarbon to $\mathrm{NO}_{\mathrm{x}}$ ratio and therefore again to higher $\mathrm{O}_{3}$ production efficiencies.

Therefore, the export of $\mathrm{O}_{3}$ precursors from the ABL to the FT is a crucial component of the total tropospheric $\mathrm{O}_{3}$ budget. Exchange between the ABL and the FT occurs by processes ranging from synoptic systems, squall lines, deep and shallow cumulus and dry convection down to turbulence (Fiedler, 1982). Of these, only synoptic systems are resolved in GCTMs, with typical horizontal grid resolutions of $\sim 2^{\circ} \times 2^{\circ}$, whereas all other processes have to be parameterized. Vertical transport by deep, moist convection has 

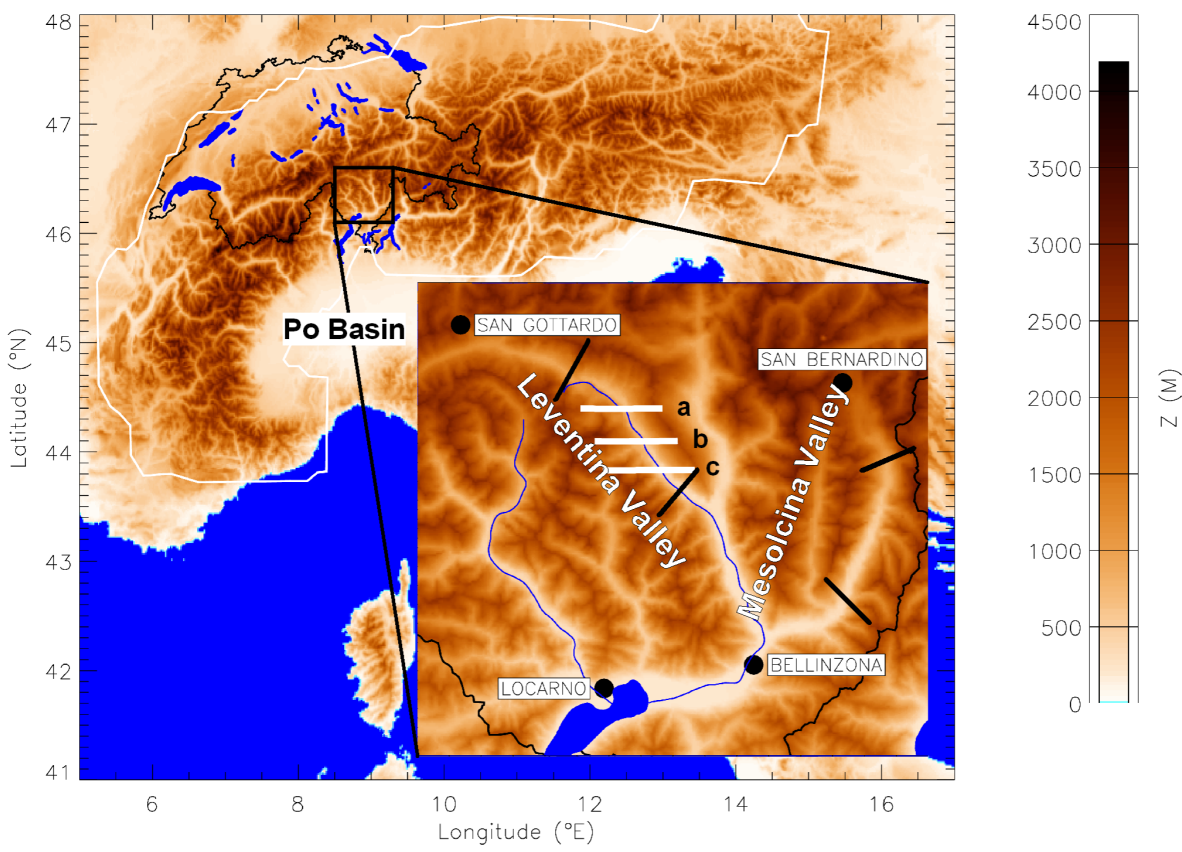

Fig. 1. Investigated valleys in southern Switzerland. White solid lines a-c indicate lidar transects above the Leventina Valley. Black solid lines represent cross-sectional flights of the MetAir aircraft used for the mass budget calculation.

been quantified in the last two decades (Cotton et al., 1995) and is parameterized in GCTMs (Jacob et al., 1997). Its influence on global $\mathrm{O}_{3}$ budgets, however, is still under debate (Lelieveld and Crutzen, 1994). Parameterizations of dry, shallow convection in GCTMs assume ABL mixing, and hold for flat and homogeneous terrain. Above complex terrain (mountainous or coastal), however, thermal wind systems in the range of 0.1 to $100 \mathrm{~km}$ develop due to differential heating or cooling of the Earth's surface during clear sky and strong radiation conditions with weak synoptic forcing (fair weather). Export of trace gases from the ABL in complex terrain to the FT occurs through gaps in the ABL inversion (Kossmann et al., 1999), called topographic venting in the following. Once in the FT, pollutants might be recirculated regionally on a time scale of a few days (Millan et al., 2002; Tyson and D'Abreton, 1998). Elevated layers in the FT are frequently observed (McKendry and Lundgren, 2000; Newell et al., 1999), indicating long-range transport of ABL constituents. Entrainment of elevated pollution layers into the ABL leads to increased surface pollutant concentrations at remote sites (Berkowitz et al., 2000).

For high altitude research sites like the Jungfraujoch (JFJ, $3580 \mathrm{~m}$ a.s.1.) in the central Swiss Alps, diurnal variation of air pollutants originating from the ABL can be observed during daytime fair weather days, especially during the summer season (e.g. Baltensperger et al., 1997; Nyeki et al., 1998; Forrer et al., 2000; Zellweger et al., 2000). It was questioned if the site is influenced by local slope flows bringing polluted air upwards, or if a regional pollutant increase at this altitude above the Alps occurs. Baltensperger et al. (1997) concluded that slope winds over a certain catchment area are responsible for vertical transport of $\mathrm{ABL}$ pollutants. A trajectory study within the EUROCTRAC sub-project ALPTRAC (High Alpine Aerosol and Snow Study) revealed that polluted air arriving at JFJ and at the Sonnblick mountain observatory (3106 $\mathrm{m}$ a.s.l., Austria) is significantly influenced by sub-grid processes (like orographic thermal circulations) not resolved by operational models, manifested in typical diurnal variation patterns (Seibert et al., 1998).

During the VOTALP (Vertical $\mathrm{O}_{3}$ transport in the Alps) (Wotawa and Kromp-Kolb, 2000) project $\mathrm{O}_{3}$ transport towards and within the Alps was investigated. It was shown that horizontal transport and $\mathrm{O}_{3}$ formation along the pathways on scales of $10-100 \mathrm{~km}$ strongly influence $\mathrm{O}_{3}$ concentration in the Alps (Wotawa et al., 2000). South foehn events were found to increase $\mathrm{O}_{3}$ concentrations in areas influenced by foehn (Seibert et al., 2000). Vertical transport within the Mesolcina valley in southern Switzerland was found to be large on days with strong solar irradiation (Furger et al., 2000). Ground based lidar observations in the Mesolcina valley showed an increase in backscatter ratios above crest height in the afternoon hours (Carnuth and Trickl, 2000). In addition, the increase of VOC concentrations above crest height between morning and afternoon could be related to vertical transport of in-valley traffic emissions (Prevot et al., 2000).

This paper investigates the mechanism of topographic venting within deep Alpine valleys. Air mass export from 
the ABL to the FT is quantified by means of air mass budgets. Pollutant export and $\mathrm{O}_{3}$ chemistry will be addressed in future work.

\section{Measurements and methods}

\subsection{Experimental setup}

The VOTALP and CHAPOP (Characterization of high Alpine pollution plumes) field campaigns took place in the Mesolcina and Leventina valleys in the southern Swiss Alps (Fig. 1). The Leventina valley leads to the San Gottardo road tunnel and the Mesolcina valley to the San Bernardino road tunnel. Steep slopes (slope angle between $20^{\circ}$ and $\left.25^{\circ}\right)$, small floor width $(0.3 \mathrm{~km}$ to $1.0 \mathrm{~km})$ and large depth $(1.5 \mathrm{~km}$ to $2.0 \mathrm{~km})$ are characteristic of both valleys. Major transalpine traffic routes within the Mesolcina and Leventina valleys $(\sim 500$ (Mesolcina) and $\sim 4500$ (Leventina) trucks per working day) represent a substantial $\mathrm{NO}_{\mathrm{x}}$ source at the valley floor of approximately 1 and $10 \mathrm{~kg}(\mathrm{~N}) \mathrm{km}^{-1} \mathrm{~d}^{-1}$, respectively. The emissions are calculated for the specified traffic load using an emission factor for an average European truck fleet and an average incline of the road of $\pm 4 \%\left(2.23 \mathrm{gN} \mathrm{km}^{-1}=7.33 \mathrm{~g} \mathrm{~km}^{-1} \mathrm{NO}_{\mathrm{x}}\right.$ as $\mathrm{NO}_{2}$; BUWAL and UBA, 1999).

The measurement setup of the VOTALP Mesolcina experiment is described in detail by Furger et al. (2000). During the CHAPOP Leventina experiment multiple aircraft were used to investigate the structure and chemical composition of the valley's atmosphere. On three flight days (26-28 August 2001) a small research aircraft (Neininger et al., 2001) operated by the Swiss MetAir acquired meteorological, chemical and aerosol parameters by flying cross sections within the valley (thick black lines in Fig. 1). Flow measurements will be used for mass budget analysis of the up-valley flow (see Sect. 2.2). The MERLIN IV research aircraft (Meteo France) flew a box grid pattern at an altitude of 3-4 km a.s.l., measuring parameters similar to the MetAir aircraft. The measurements of wind, temperature and humidity provide important information about the flow structure in a layer above crest height on a more regional scale. The FALCON research aircraft of the German Aerospace Center (DLR) carried a nadir-pointing aerosol lidar at a height of $8 \mathrm{~km}$ a.s.l. that supplied information about aerosol distribution and ABL development, not only for the valley atmosphere but also for the whole Ticino region. The nadir-pointing backscatter lidar, operated by the DLR (Kiemle et al., 1995), was used to observe the structure of the ABL at wavelengths $\lambda=354$, 532 and $1064 \mathrm{~nm}$. The backscatter ratio $\beta$, which is determined by the lidar, is the ratio of the total backscatter (Mie+Rayleigh) to Rayleigh backscatter. Since high relative humidity (RH) values lead to aerosol growth and therefore enhanced Mie scatter, $\beta$ is enhanced in regions with high aerosol concentration and high RH. Hence, a direct compar-

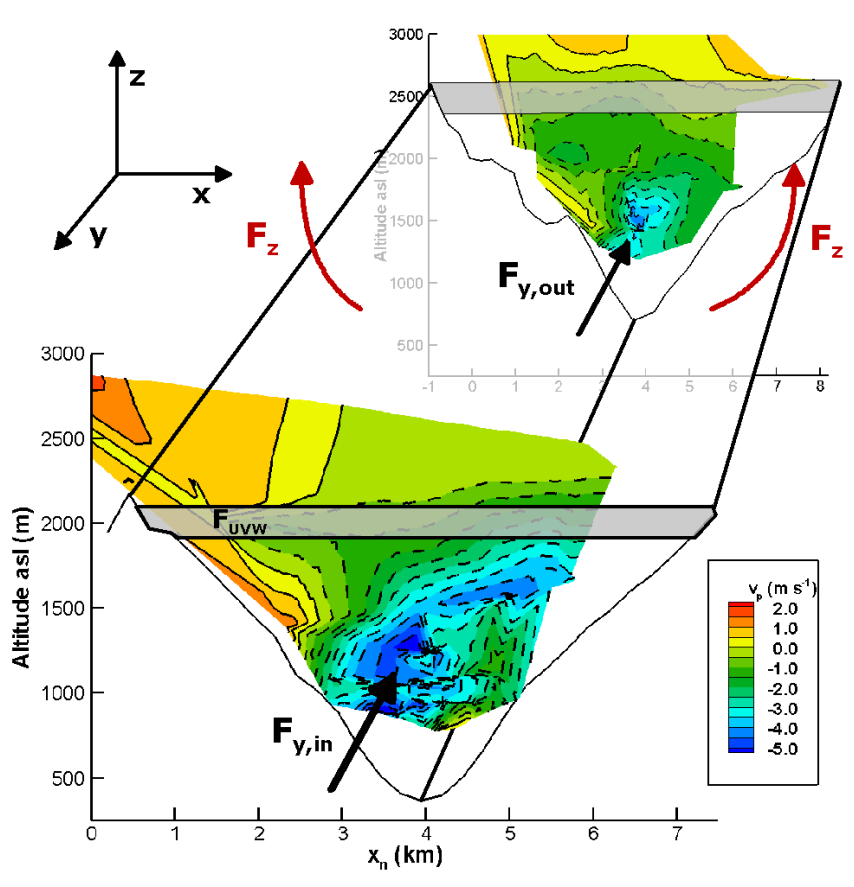

Fig. 2. Air flow in the Leventina valley at 10:00 UTC on $26 \mathrm{Au}-$ gust 2001. Horizontal mass fluxes $F_{y, \text { in }}$ and $F_{y}$, out and change of up-valley wind layer air mass with time $F_{U V W}$ as measured by the MetAir aircraft. The horizontal direction $x_{n}$ is perpendicular to the valley axis, the y direction points down-valley. The contour plot depicts wind velocity parallel to the valley axis $v_{p}$. Negative values indicate up-valley flow (dashed contour lines), positive values down-valley flow (solid contour lines).

ison in terms of aerosol concentrations between different altitudes and distant regions is not always sensible.

Radiosondes measuring atmospheric pressure, temperature, humidity, and wind (ZEEMET ${ }^{\mathrm{TM}}$ Mark II MICROSONDE) were launched in the center of the valley. The radiosondes were launched for a period of 5 days with a temporal resolution of 3 hours. Therefore, these soundings provide important information about the flow structure not only during the day but also during the night and transition periods. Continuous measurements of standard chemical and meteorological surface parameters were conducted during five weeks (August and September 2001) at three sites, including formaldehyde and detailed VOC analysis. Meteorological data was gathered at two additional sites at the valley's north-eastern slope. A sodar wind profiling system (Remtech, PA2) was situated at the north-eastern crest of the Leventina valley (Monte Matro, $2172 \mathrm{~m}$ a.s.l., eastern side of lidar transect $\mathrm{c}$ in Fig. 1) and acquired three-dimensional flow data up to $800 \mathrm{~m}$ a.g.l. Ambient air measurements and meteorological observation identify the analyzed days of flight to be typical fair weather days. The information on pollutant concentrations will be used in a further analysis of the $\mathrm{O}_{3}$ production within and above Alpine valleys. 

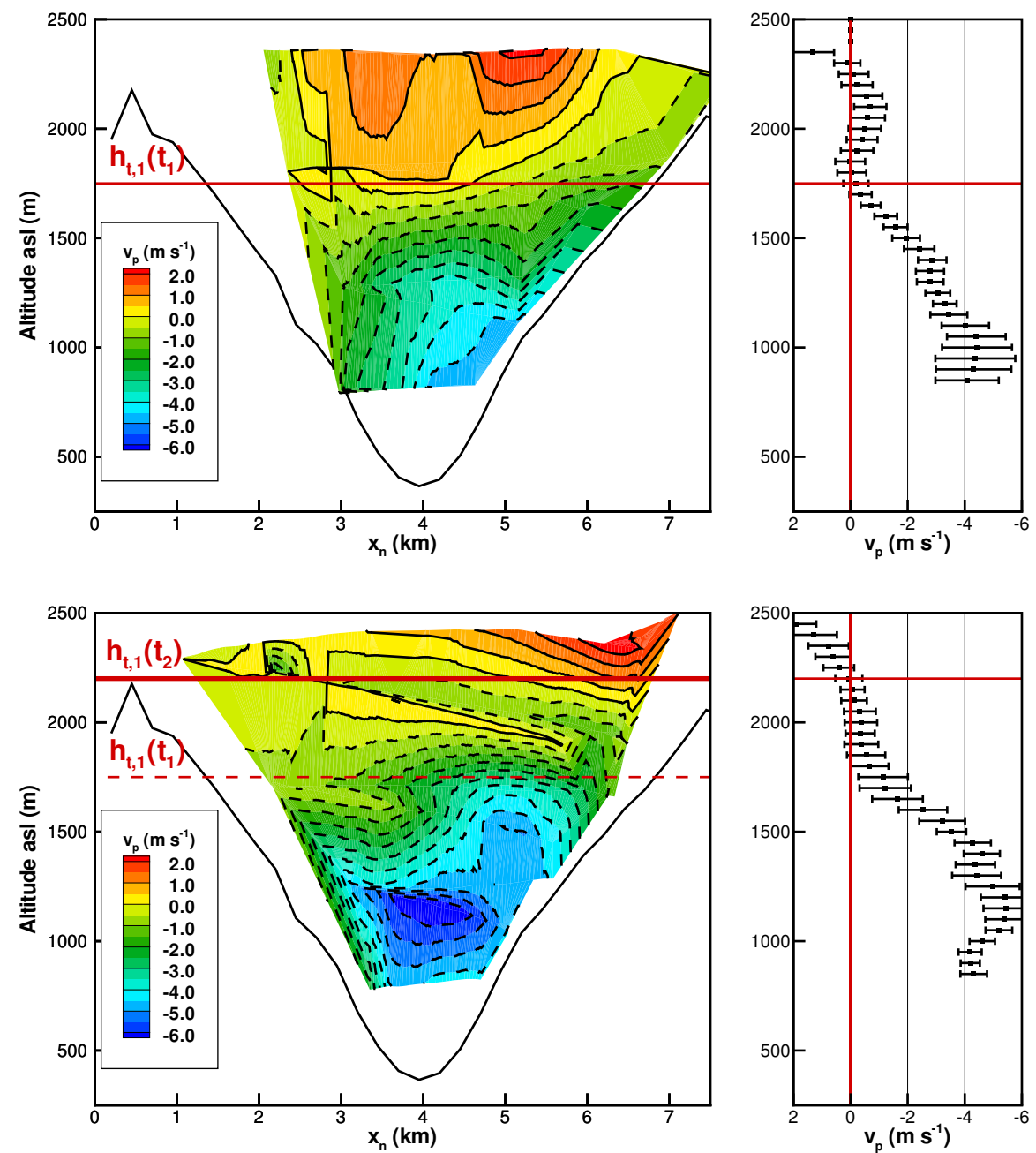

Fig. 3. Change of up-valley wind with time. Contour plot (left) of valley parallel wind velocity $v_{p}$ at cross section within Leventina valley on 28 August 11:45 UTC (upper figures) and 13:30 UTC (lower figures) and vertical profile of horizontal averaged $v_{p}$ (symbols) and its standard deviation (error bars) at an individual altitude (right). Change of up-valley wind layer height $z_{U V W}$ with time is indicated in lower figure. The example shows a rather strong change of the up-valley wind layer height to illustrate the effect. Usually the change of the up-valley wind layer height was much smaller.

\subsection{Mass budget}

We conducted air mass budget calculations for thermal airflow in the Mesolcina and Leventina valley to quantify vertical air mass export to the FT during daytime, fair weather conditions. Mass budgets can help to quantify the pollutant export to the free troposphere. The dilution ratio of ABL air with FT air above an Alpine valley might be crucial for $\mathrm{O}_{3}$ production in the mixed air mass and therefore for the question of $\mathrm{O}_{3}$ export.

Differential heating within a mountainous environment results in up-valley airflow parallel to the valley floor during the day (up-valley wind). At the valley sidewalls, up-slope winds prevail (Defant, 1949; Whiteman and Dreiseitl, 1984), potentially penetrating the $\mathrm{ABL}$ inversion and resulting in export of polluted $\mathrm{ABL}$ air.

Vertical wind velocities in thermal updrafts or slope flows can be as high as a few meters per second. However, they are also often spatially and temporally intermittent. Estimating the vertical mass flux out of a valley atmosphere due to slope winds and vertical updrafts by direct measurements of the vertical wind velocity is therefore a difficult task. In this work we use an indirect method to determine the vertical mass export from the ABL within the up-valley wind system to the FT as a residual of horizontal flow measurements.

For budget calculation purposes, a valley segment is composed of a minimum of three open interfaces, two vertical cross sections within the main valley and a horizontal lid. 
Additional flow into or out of tributary valleys $F_{T}$ has to be considered. Due to conservation of mass, the net vertical mass flux $F_{z}$ is governed by the convergence of the horizontal mass fluxes $F_{y, \text { out }}-F_{y, \text { in }}, F_{T}$ and the change of the up-valley wind layer air mass with time $F_{U V W}$ :

$F_{z}=F_{y, \text { out }}-F_{y, \text { in }}+F_{T}-F_{U V W}$.

Figure 2 shows an example of the air flow in the Leventina valley in two cross sections across the valley. Note that upvalley flow is indicated by a negative sign and that no tributary valleys are present. Two contrary motions contribute to the net vertical mass flux, upward flux (e.g. by slope winds or thermals) minus downward flux (e.g. sinking in the center of the valley). For air pollution studies the amount of air leaving the valley is of interest and is linked to the upward flux. The net vertical mass flux gives a lower limit of this value. However, for the valleys investigated in this study the downward flux due to sinking motion is thought to be small. Subsiding motion should be visible in subsiding temperature structures. The sounding measurements reveal a stable layer building up within the valley during the night. This zone of strong stability usually did not completely disappear during the day and remained rather unaltered in altitude or rose slightly during the afternoon hours. In addition, a large downward flux would need to be balanced by stronger slope wind flow (upward flux). Based on the directly measured slope wind speed, the depth of the slope wind layer necessary to balance the net vertical mass flux was calculated (Sect. 3.2). A larger flux within the slope wind layer would result in a larger slope wind layer depth. Our result for the slope wind layer depth is in the range of other studies. We therefore assume that the downward flux plays only a minor role for our budget analysis and that the net vertical mass flux is close to the upward mass flux. Net vertical mass flux and upward mass flux will be used synonymously in the following.

The flow in the slope wind layer depends on the energy input to this layer by the sensible heat flux at the slope surface, atmospheric stability and the slope angle (Vergeiner and Dreiseitl, 1987). The larger the sensible heat flux at the slope surface, the stronger the temperature differences between the valley center and the slope layer, providing the driving force for the slope winds. On the other hand, vertical motion is damped with increasing atmospheric stability. Near neutral stability prevents the generation of an organized slope wind due to enhanced turbulent vertical mixing (Vergeiner and Dreiseitl, 1987). Maximal upward flow was simulated in atmospheric numerical models for intermediate atmospheric stability (Atkinson and Shahub, 1994).

The valleys investigated in our study posses no tributaries. For our budget calculation only the horizontal mass fluxes $F_{y, \text { in }}, F_{y, \text { out }}$ and the change of the up-valley wind layer air mass with time $F_{U V W}$ have to be measured to yield the net vertical mass flux $F_{z}$. The horizontal mass flux through a valley segment is computed using wind data collected by the MetAir aircraft. A 5-hole gust probe (Keller capacitive sensors) provides three-dimensional wind data with a precision of $0.5 \mathrm{~m} \mathrm{~s}^{-1}$ for each component and a temporal resolution of $1 \mathrm{~s}$. The wind velocity parallel to the valley axis $v_{p}$ is horizontally averaged for layers of $50 \mathrm{~m}$ vertical extent, providing an individual vertical profile at each cross section (Fig. 3). For the lowermost part of the valley, where no wind measurements were available from the aircraft, the wind speed is assumed to follow a logarithmic wind profile, fitted to the lowest available data and a $z_{0}$ of $10 \mathrm{~m}$ for mountainous terrain (Stull, 1988). This assumption does not have a strong influence on the total horizontal mass flux because the cross sectional area without wind information is rather small compared to the whole valley cross section. On average the mass flux through the region without wind measurements made up $6 \%$ of the total horizontal mass flux through the whole cross section. The possible errors due to the assumption of a logarithmic wind profile are rather small. Air density $\rho$ is averaged for the same vertical layers. Missing data at the valley bottom is complemented by assuming a neutrally stratified atmosphere below the lowest available measurements. Integration from the valley floor $h_{0}$ up to the height $h_{t}$, where the up-valley wind ceases and $v_{p}$ changes sign (Fig. 3), yields the horizontal mass flux

$F_{y}=\int_{h_{0}}^{h_{t}} \rho(z) \cdot v_{p}(z) \cdot B(z) d z$,

where $B(z)$ is the valley width at height $z$. In the cases investigated in this study, the wind direction above the up-valley wind layer was always opposite to the up-valley flow. Hence, $v_{p}$ always changed sign at the up-valley wind layer top. Even if the flow above the up-valley wind is in the same direction as the up-valley wind itself, a minimum of the wind speed between both layers and atmospheric stability changes with height can usually be observed and used to determine $h_{t}$. The standard deviation of all wind speed recordings at an individual altitude within each cross section was used for estimating the error propagation for the horizontal mass flux. The uncertainty for each individual horizontal mass flux was averaged to yield $7 \%$. An individual cross valley flight took about $15 \mathrm{~min}$. We assume that during this short time period the change in the flow structure and intensity is not essential. The transfer flight to a subsequent cross section took about $5 \mathrm{~min}$. Therefore, the time distance between two horizontal mass flux calculations is $20 \mathrm{~min}$. The time difference, $t_{2}-t_{1}$, between two cross-sectional flights at the same cross section was typically about two hours. The horizontal mass flux changed during this time. A linear correction for the 20 min time difference between two subsequent cross sections was applied based on the changes within the two hour interval.

The change of the up-valley wind layer air mass with time is governed by the change of the up-valley wind layer height with time (Fig. 3)

$F_{U V W}=\frac{m_{V}\left(h_{l}\left(t_{2}\right)\right)-m_{V}\left(h_{l}\left(t_{1}\right)\right)}{t_{2}-t_{1}}$, 
Table 1. Net vertical mass export of the investigated valleys. Mean standard deviation of individual flux measurements is given in parentheses and derived from standard deviation of the up-valley wind velocity at each altitude level used for the horizontal flux calculation

\begin{tabular}{lccccccc}
\hline Valley & $\begin{array}{c}\text { Number } \\
\text { of flights }\end{array}$ & $\begin{array}{c}-F_{y, \text { in }} \\
\left(\frac{T g}{h}\right)\end{array}$ & $\begin{array}{c}-F_{y, \text { out }} \\
\left(\frac{T g}{h}\right)\end{array}$ & $\begin{array}{c}F_{U V W} \\
\left(\frac{T g}{h}\right)\end{array}$ & $\begin{array}{c}F_{z} \\
\left(\frac{T g}{h}\right)\end{array}$ & $\begin{array}{c}F_{z, N}^{a} \\
\left(\frac{T g}{h k m}\right)\end{array}$ & $\begin{array}{c}\text { Export rate }^{b} \\
\left(\frac{\%}{h}\right)\end{array}$ \\
\hline $\begin{array}{l}\text { Leventina } \\
\text { (August '01) }\end{array}$ & 4 & $51(3)$ & $22(3)$ & 5.6 & $24(4)$ & $1.5(0.3)$ & $30(5)$ \\
$\begin{array}{l}\text { Mesolcina } \\
\text { (July '96) }\end{array}$ & 2 & $69(5)$ & $35(1)$ & -1.4 & $35(5)$ & $1.8(0.3)$ & $28(4)$ \\
$\begin{array}{l}\text { Mesolcina } \\
\text { (June '98) }\end{array}$ & 2 & $113(5)$ & $38(3)$ & 3.2 & $71(5)$ & $3.7(0.4)$ & $42(3)$ \\
\hline Average & - & - & - & - & 39 & 2.1 & 33 \\
\hline
\end{tabular}

$a$ The net vertical mass flux divided by the length of the valley segment.

${ }^{b}$ Percentage export of the up-valley wind layer mass.

where $h_{l}$ is the mean height of up-valley wind layer at the lower and the upper cross section. The valley's air mass, $m_{V}$, is derived from digitized topographic data and for standard atmospheric conditions.

During the VOTALP campaign valley-parallel wind velocities were continuously measured with scintillometers (Poggio et al., 2000). They used 5 different optical paths across the valley with lengths between 0.9 and $2.7 \mathrm{~km}$. The heights of the optical paths above the valley floor were between 60 and $600 \mathrm{~m}$. They observed an increasing up-valley wind speed from about 7:00 to 10:00 UTC and rather stable wind speeds afterwards (see their Figs. 13, 15, 16). In addition, the wind speed measured within 10-minute intervals at surface stations in the Leventina valley deviated only by $16 \%$ from the two-hour averages. This underlines the stationary upvalley flow and justifies the assumptions made for the mass budget calculation. In contrast, an observational and numerical study in the nearby Riviera valley shows that the structure and intensity of the up-valley flow undergoes significant changes during the day and shows intermittent character (?). This might be due to a different valley configuration and different synoptic forcing.

For nighttime drainage flows, different methods to quantify $F_{y}$ have been used in other studies, showing uncertainties arising from individual vertical profile measurements (King, 1989). In contrast, individual vertical profiles used in this study do not represent a vertical profile above a single point at the cross section, but represent an average for the whole cross section. Horizontal mass fluxes were calculated with the individual vertical profile method and from two-dimensional interpolations of the measured wind data at the cross sections. Both methods differed only \pm 7 to $11 \%$ from each other, depending on interpolation scheme (Kriging, Inverse-Distance or Linear interpolation) and parameter settings (scaling of vertical to horizontal distance).

\subsection{Forward trajectories}

Forward trajectories were used to analyze the pathways of an air mass that was influenced by topographic venting above Alpine terrain. Ambient air composition might be influenced in regions where this air mass is entrained into the ABL. Trajectories were initialized at three sites north and south of the main Alpine crest and at different altitudes.

We used the FLEXTRA trajectory model (Stohl et al., 1995) based on European Center for Medium-Range Weather Forecasts (ECMWF) analysis. For the years 2000 and 2001, days that were favorable for topographic venting were selected. Since the energy flux at the Earth's surface plays a very important role in supporting thermal wind systems, a simple criterion to select fair weather days was chosen. Days with more than $9 \mathrm{~h}$ of sunshine at selected stations at the northern and the southern side of the main Alpine crest within Switzerland were selected. Ten stations, covering the whole Swiss plateau, and four stations, covering the Ticino area in the south, were chosen. $50 \%$ of the northern stations and $50 \%$ of the southern stations had to fulfill the criterion. A total of 101 days within the two-year period were selected. Valley and slope winds also develop on days with less solar irradiation (Atkinson, 1981), but for this study the focus is on days comparable to the days of the mass budget analysis. The selected days lie in the period from the end of March to the beginning of October. Sunshine data was taken from the automatic network of meteorological observations maintained by the Swiss national weather service (MeteoSwiss).

\section{Results}

\subsection{Export of boundary layer air}

Horizontal mass fluxes and the change of the up-valley wind layer mass with time were computed from a database of 8 


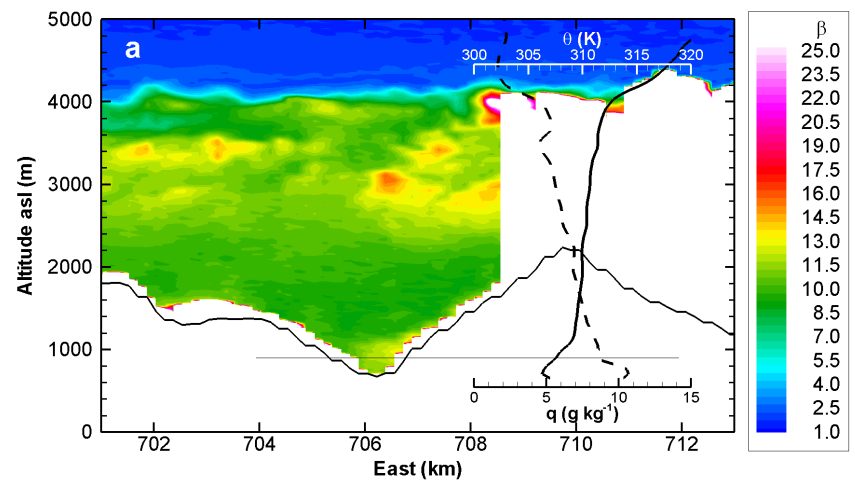

Fig. 4. Atmospheric backscatter ratio $\beta$ for lidar transect within the Leventina valley on 28 August 2001 from 13:36 and 13:56 UTC, $\lambda=1064 \mathrm{~nm}$. Horizontal coordinates refer to Swiss coordinate system, view is towards north. The Transect corresponds to the white solid lines labeled a in Fig. 1 and Fig. 7. The surface as seen by the lidar differs slightly from digitized topographic data with $250 \mathrm{~m} \times 250 \mathrm{~m}$ horizontal resolution (black solid line). The lidar beam does not penetrate clouds, represented by white areas. Potential temperature $\theta$ (solid black line) and specific humidity q (dashed black line) as measured by a radio sonde launched at 12:00 UTC at the valley floor close to the transect are included. The thin black horizontal line indicates the average CBL height as taken from the radio soundings. The CBL top varies along the cross section as well as from one cross section to the other.

flights within both valleys and from digitized topographic information. In order to compare the estimated vertical mass fluxes they are normalized by the length of the investigated valley segment and the air mass of the up-valley wind layer, respectively. In this way, the mass export per unit valley length and the fraction of ABL air exported per hour is obtained for each valley. We derived an average net vertical export of $33 \%$ of the up-valley wind layer air mass per hour (Table 1). This export rate is similar in both Mesolcina and Leventina valleys, and was somewhat higher in June compared to July and August. In June the vertical mass flux per valley length $F_{z, N}$ is twice as high as in July and August. On the other hand, the up-valley wind layer height was also larger in June so that the export rate is only one third larger in June compared to July and August. Atmospheric stability (between the valley floor and $4000 \mathrm{~m}$ a.s.1.) was lower for the cases in June than for August and July. Since the number of measurement days is limited, a final conclusion on atmospheric stability being the major factor influencing the vertical mass flux can not be drawn. Other factors like synoptic forcing and subsidence, cumulus formation, solar irradiation and different Bowen ratios at the surface might play an important role. Again their influence can not be investigated with the limited data set.

Up-valley flow conditions persist for about $7-9 \mathrm{~h} \mathrm{~d}^{-1}$ during the summer season at this latitude, resulting in venting to the lower FT of 2.3-3.0 times the up-valley wind layer air mass per day.

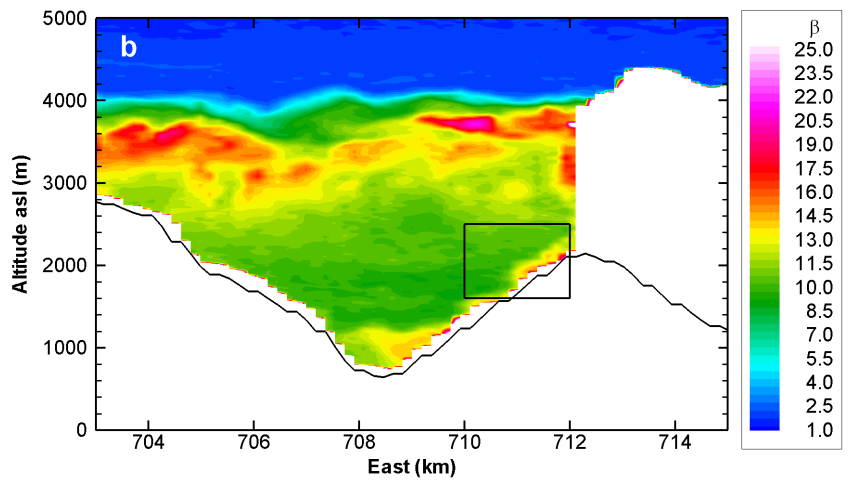

Fig. 5. Same as Fig. 4 but for transect b. See Fig. 8 for blow up of slope wind layer (black rectangle).

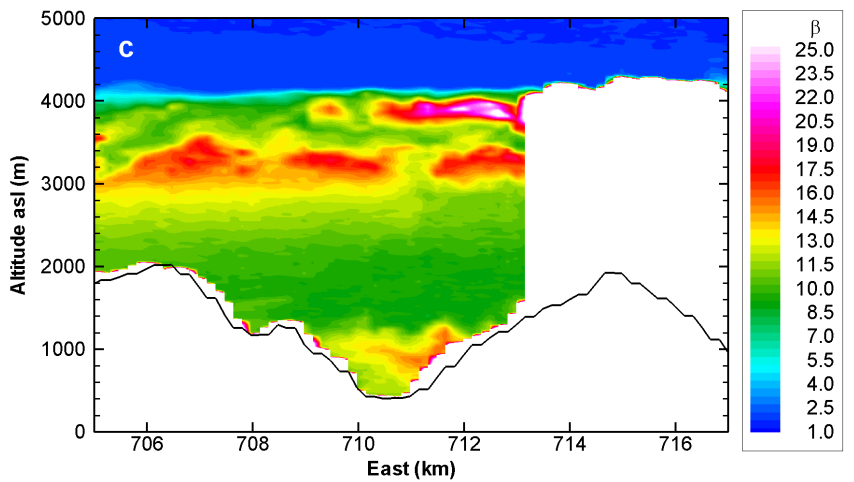

Fig. 6. Same as Fig. 4 but for transect c.

\subsection{Boundary layer structure}

Figures 4 to 6 show a sequence of three cross-valley transects from north (Fig. 4) to south (Fig. 6) within the Leventina valley. Two different aerosol layers are evident. The area below $1000 \mathrm{~m}$ a.s.l. can be interpreted as the convective boundary layer (CBL) within the valley. Comparison with balloon soundings of potential temperature $\theta$ and specific humidity $q$ (Fig. 4) shows that the top of the CBL is even below the top of the area of increased $\beta$. In a CBL, superadiabatic lapse rates (i.e., decreasing $\theta$ with height) often occur close to the ground, where air gathers in thermal plumes and starts to rise, whereas $\theta$ increases at the top of the CBL, where entrainment occurs. However, the entrainment zone extends only through about $20 \%$ (depending on definition) of the CBL, whereas the bulk of the CBL has a close to neutral stratification (i.e., constant $\theta$ ). The region with high aerosol concentrations does not necessarily correspond to the actual CBL height, but could be attributed to previous mixing (Seibert et al., 2000).

The convective boundary layer height shown in Fig. 4 is relatively low compared to other days. Unfortunately, there are no backscatter data available on other days. Typically, the top of the CBL was detected at $2000 \mathrm{~m}$ a.s.l. from potential 

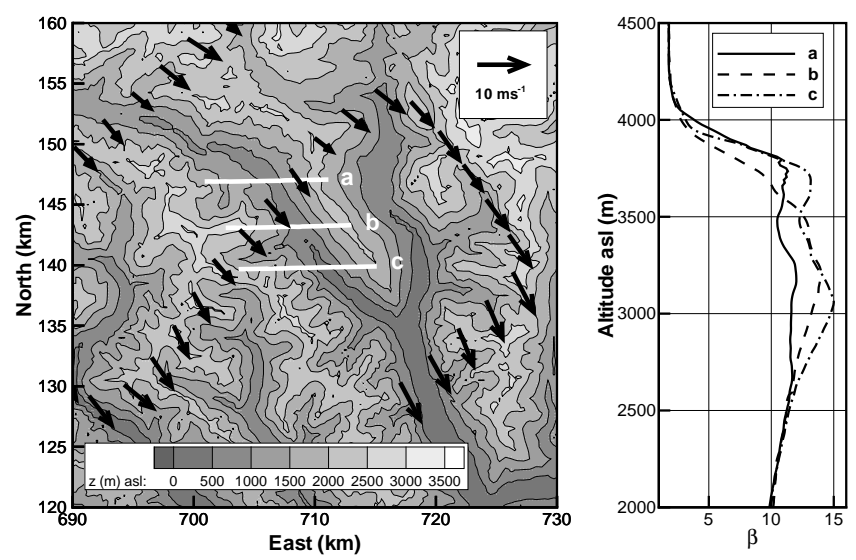

Fig. 7. Left: Flow at $3900 \mathrm{~m}$ a.s.l. above Leventina valley, $28 \mathrm{Au}-$ gust 2001, 12:00 UTC. Coordinates refer to Swiss coordinate system. White solid lines represent lidar transects in Figs. 4 to 6. The length of the vectors are proportional to the wind velocity. Right: Mean vertical profiles of backscatter ratio $\beta$ for transects a-c.

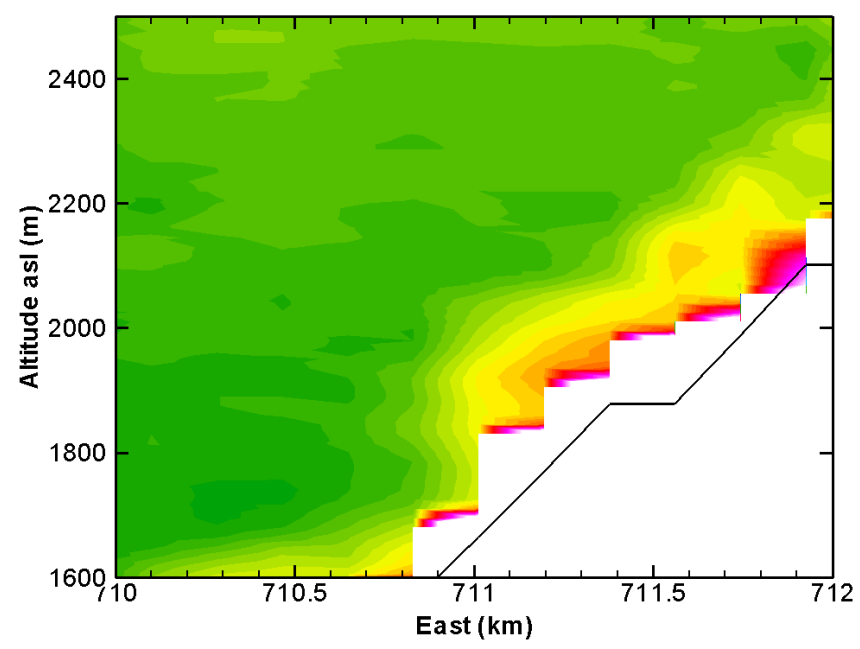

Fig. 8. Same as Fig. 5, but magnified slope wind layer.

temperature profiles. The prevailing wind was coming from the west to the northwest in the second layer, reaching from $1000 \mathrm{~m}$ a.s.l. up to $4100 \mathrm{~m}$ a.s.l. Wind data shown in Fig. 7 were measured by the MERLIN IV research aircraft at an altitude of $\sim 3900 \mathrm{~m}$ a.s.l. Horizontally averaged backscatter ratios increased from northwest to southeast (Fig. 7), indicating the additional injection of ABL air into the second layer while being advected horizontally by the synoptic flow. Increased backscatter ratios are also observed in the slope wind layer (Figs. 5 and 8), indicating up-slope transport of aerosols and moisture from the ABL.

Assuming that the whole vertical mass flux, as derived by the budget method, occurs within the slope wind system, the corresponding up-slope wind depth was evaluated. Typical slope wind velocities measured during the CHAPOP cam-

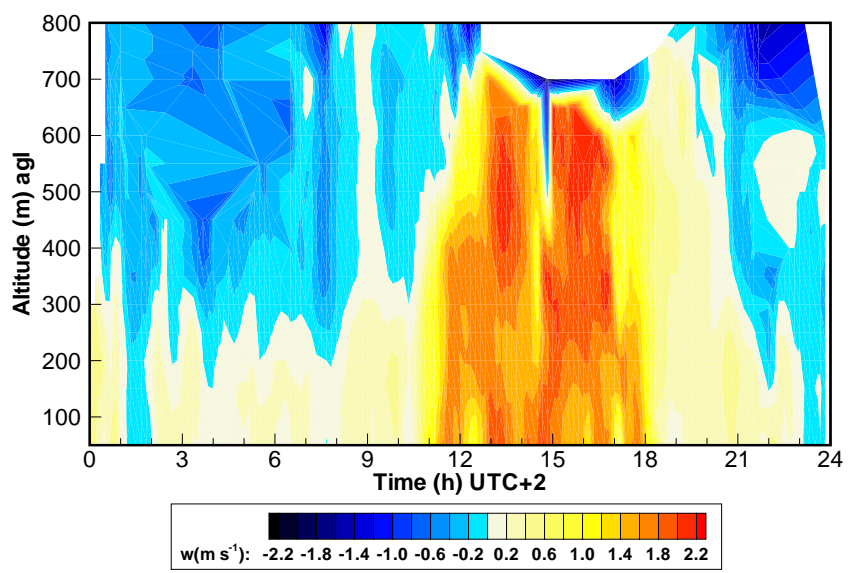

Fig. 9. Evolution of vertical wind velocities above the north-eastern crest of the Leventina valley on 28 August 2001. Yellow to red colors indicate upward motion, blue to black colors indicate downward motion.

paign were $\sim 2 \mathrm{~m} \mathrm{~s}^{-1}$. The estimated slope wind depth of $\sim 100 \mathrm{~m}$ is similar to depths observed directly in other studies (Kossmann et al., 1999). This suggests that slope winds are the most important mechanism for vertical export of ABL air. This is also supported by strong upward motion observed by the sodar wind profiling system (Fig. 9) above the crest, where the winds of two slopes merge. Vertical velocities of more than $\sim 1.5 \mathrm{~m} \mathrm{~s}^{-1}$ can be seen from 10:00 UTC to 16:00 UTC ranging up to $700 \mathrm{~m}$ above ground level. During the night, sinking motion persists due to the larger scale subsidence and possibly local down-slope flow. However, the downward motion during the night is generally much weaker than the upward motion during the day.

In other studies, elevated layers have been observed downwind of the Alps and over the Adriatic Sea (Nyeki et al., 2002), indicating horizontal transport of ABL air masses that might have been lifted above mountainous terrain. Elevated layers are frequently observed even further away above the eastern Mediterranean (Lelieveld et al., 2002), caused by other lifting processes including topographic venting. In the western Mediterranean pollution recirculation caused by the interaction of sea breezes and up-slope winds was observed, forming elevated reservoir layers of $\mathrm{O}_{3}$ (Millan et al., 2002).

\subsection{Forward trajectories}

On days with fair weather conditions for the years 2000 and 2001, two ensembles of forward trajectories with an initial altitude of $3428 \mathrm{~m}$ a.s.l. were identified (Figs. 10 and 11). This altitude corresponds to the altitude that is reached by topographic venting. In the first ensemble, air masses move in a southerly direction and slowly descend within the subtropical anticyclone above the Mediterranean and North Africa. Contained pollutants possibly influence surface concentrations or remain in reservoir layers (Lelieveld et al., 2002; 


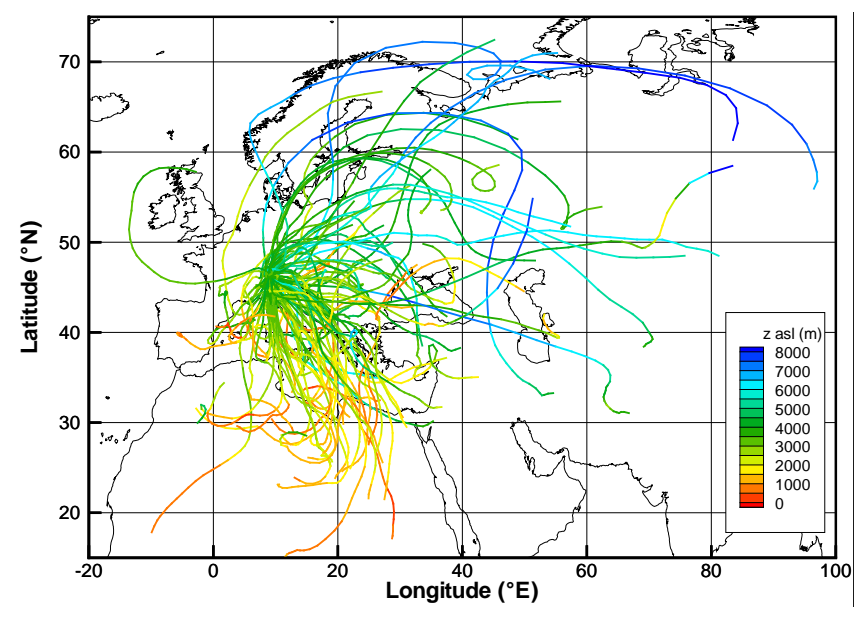

Fig. 10. Forward trajectories initialized at $3428 \mathrm{~m}$ a.s.1. above Gotthard region $\left(8^{\circ} 58^{\prime} \mathrm{E}, 46^{\circ} 21^{\prime} \mathrm{N}\right)$ at 16:00 UTC on fair weather days for the years 2000 and 2001. Colors indicate the altitude of the air mass above sea level.

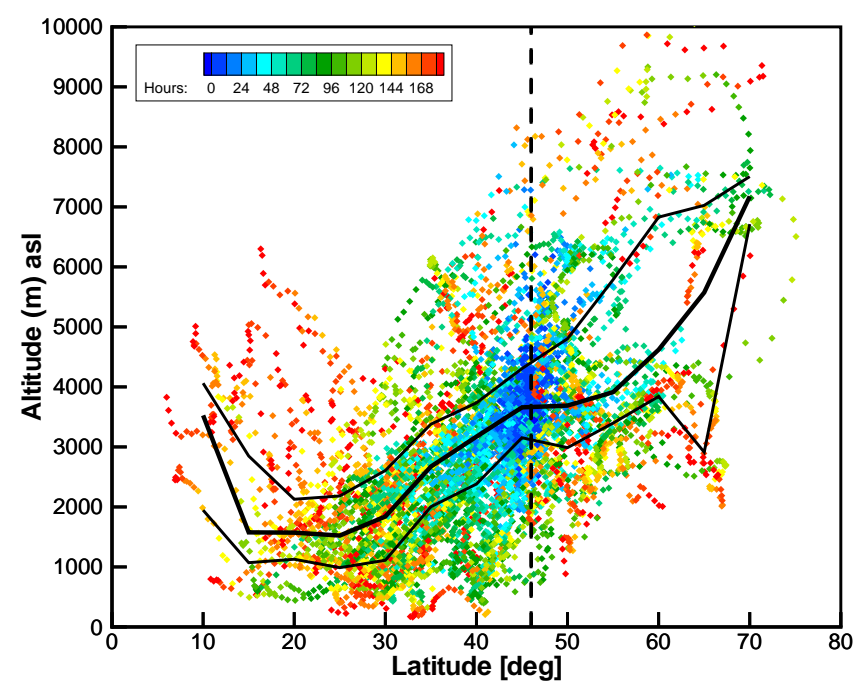

Fig. 11. Altitude of the trajectories shown in Fig. 10 versus latitude. Symbols represent individual trajectory points. Color coding refers to the hours since the trajectory was started. The black line indicates the median height of all trajectory points in $5^{\circ}$ latitudinal bins. Thin black lines represent the corresponding lower and upper quartiles.

Traub et al., 2003). In the second ensemble, air masses move northward and ascend up to $9000 \mathrm{~m}$ a.s.l. influencing the whole tropospheric column, experiencing increased westerly flow and leading to transport towards Asia. Similar results were obtained for trajectories that were initialized at all three sites. However, the results change for different initial altitudes (Fig. 12). North of the Alps the differences in initial altitudes disappear. South of the Alps lower initial altitudes cause the air to descend faster and travel slower southwards than for higher initial altitudes. Only $1 \%$ of all for-

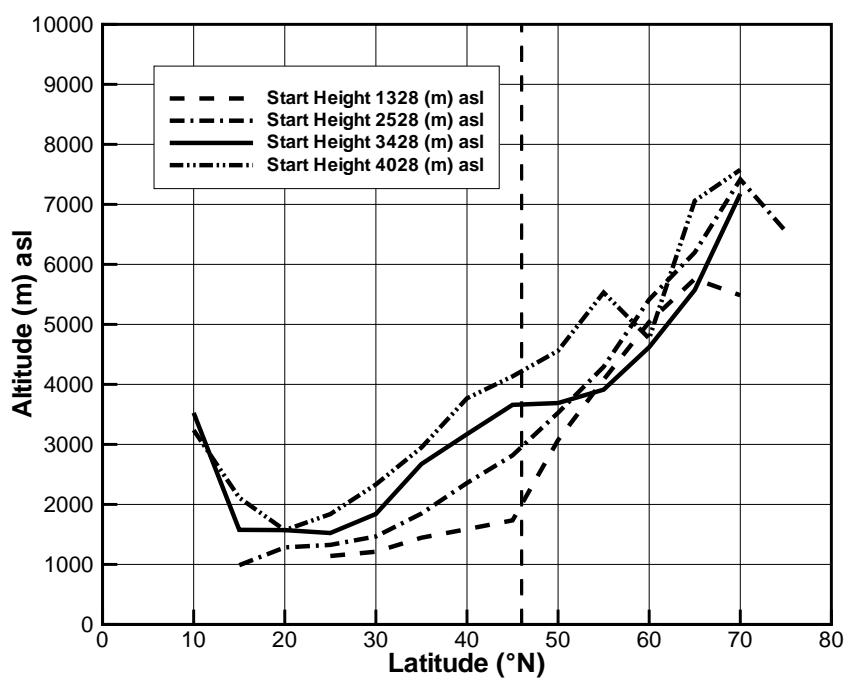

Fig. 12. Median altitude of trajectories versus latitude ( $5^{\circ}$ bins). Ensembles with different initial altitudes.

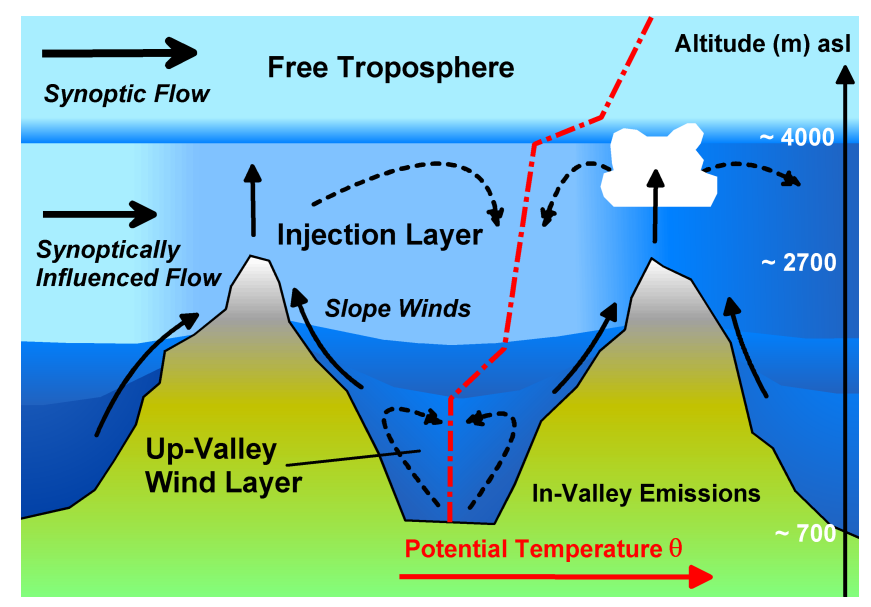

Fig. 13. Schematic of the daytime atmospheric structure and vertical pollution transport in and above deep Alpine valleys. Altitudes given represent typical values for the cases studied. Typical potential temperature profile is indicated by dashed-dotted red line. See text for details.

ward trajectories initialized below $2 \mathrm{~km}$ a.s.l. reach the FT south of $20^{\circ} \mathrm{N}$ within 8 days. In contrast, $10 \%$ of trajectories initialized at $3500 \mathrm{~m}$ a.s.l. arrive in the same region and within the same time, and begin to ascend in the intertropical convergence zone (ITCZ) potentially reaching the upper troposphere and lower stratosphere. This pathway for European ABL pollutants would result from preceding topographic venting above the Alps or other lifting processes. 


\section{Discussion}

The processes contributing to the "topographic venting" under fair weather daytime conditions are summarized in Fig. 13, expanding a similar figure proposed by Seibert (1996) in the context of ALPTRAC. Pollutants are emitted mainly at the valley floor or advected horizontally by the upvalley wind from the forelands. Within the valley, a wellmixed boundary layer $\left(\mathrm{NO}_{\mathrm{x}}\right.$ mixing ratios of about $\left.10 \mathrm{ppbv}\right)$ is capped by a rather stable layer indicated by an increase of potential temperature (dashed-dotted line). Up-slope winds are able to penetrate this layer and lift polluted air from lower levels. Additional shallow cumulus cloud formation above the crests further maintains vertical motion. Above the stable layer horizontal airflow is mainly synoptically driven. In contrast to the ABL, the upper layer is only partly mixed and is indirectly connected to the surface, therefore the term "injection layer" is used $\left(\mathrm{NO}_{\mathrm{x}} \sim 1 \mathrm{ppbv}\right)$. The injection layer is capped by a strong inversion that marks the transition to the FT $\left(\mathrm{NO}_{\mathrm{x}} \sim 0.1 \mathrm{ppbv}\right)$. The mass balance of the slope flow system is not closed in the two-dimensional valley cross section but in a three-dimensional way by the up-valley wind.

Extrapolating the high export rates derived for the Leventina and the Mesolcina valleys to the whole Alpine region, we estimated the total $\mathrm{NO}_{\mathrm{x}}$ export by thermal wind systems in the Alps. The estimate is a crude number that mainly underlines the potential of topographic venting. Using digitized topographic data $(1 \mathrm{~km} \times 1 \mathrm{~km}$ resolution) we observe that slope angle and slope extent for the investigated valleys are characteristic of about $25 \%$ of the Alpine terrain above $1500 \mathrm{~m}$ a.s.l. Slope angle is estimated by calculating the gradient vector on the topography. Values for the Leventina and Mesolcina valley are in the range of $17-27^{\circ}$. Large slope angle and large slope extent (and therefore deep valleys) are found especially in the tributaries of the major Alpine valleys (e.g. Inn, Rhone, Rhine; slope angle $\sim 25^{\circ}$ ). Lower values are typical for the central Alps $\left(\sim 10^{\circ}\right)$. Large slope angle and extent alone might not necessarily lead to similar export rates. Net sinking motion above parts of the Inn valley (Austria) was observed in a study by Freytag (1987). Unlike the valleys investigated in this study the Inn valley shows a nearly non sloping valley ground and a width of about $10 \mathrm{~km}$. In addition, assumptions, concerning the flow into tributaries had to be made. Downward vertical mass flux was also suspected to occur in the Himalayan Kali Gandaki valley (Egger et al., 2000), probably caused by a hydraulic jump (Zangl et al., 2001). This presumption could not be verified by measurements of temperature and moisture in a second field campaign (Egger et al., 2002). Rucker (2003) found negative vertical mass flux for a small section of the Wipp valley. On a local scale these findings seem reasonable, but regarding the whole valley domain, the up-valley flow has to leave the valley atmosphere at some point, at latest at the end of the valley. The result is a net upward flux of mass. Strong and dominating subsidence of clean free tropospheric air into Alpine valleys during strong solar irradiation days, such as those investigated in our study, would also contradict the findings of elevated aerosol layers on a regional domain above the Alps, as observed by Nyeki et al. (2000) and simulated by De Wekker et al. (2004b), and the general concept of a Alpine scale daytime heat-low. Climatological investigations within the Alpine domain would be required to better quantify the overall export rate. Since most $\mathrm{NO}_{\mathrm{x}}$ emissions take place at steep sections of the transalpine traffic routes in the major valleys or in their tributaries, the whole area above $1500 \mathrm{~m}$ a.s.l. is considered to contribute to vertical transport. During daytime fair weather conditions a plain-to-mountain wind, which results from differential heating between the plain and the mountains, was observed in the Bavarian foreland (Lugauer and Winkler, 2002). We find similar advection velocities of $1.5 \mathrm{~m} \mathrm{~s}^{-1}$ at stations on the Swiss Plateau and in southern Switzerland. This thermal wind system persists at least about 9 hours per day during the summer half year. Therefore, a non-negligible fraction of pre-Alpine emissions is carried to the mountains and is vertically lifted there. Our export calculation is based on an emissions inventory with a $10 \times 10 \mathrm{~km}$ grid with temporal resolution of $1 \mathrm{~h}$ (based on EMEP 1990, (The Cooperative Programme for Monitoring and Evaluation of the Long-range Transmission of Air Pollutants in Europe)). Topographic venting and plain-to-mountain flow are assumed to prevail from 09:00 to 18:00 UTC. A catchment area for every hour of this period is defined based on the $1500 \mathrm{~m}$ a.s.l. isoline and an advection velocity of $1.5 \mathrm{~m} \mathrm{~s}^{-1}$. Emissions within the catchment area are summed and integrated for the whole time period. Accumulation of nighttime emissions in the ABL, but no day-to-day accumulation, is accounted for. Chemical transformations are neglected. It is worth mentioning that oxidation products of $\mathrm{NO}_{\mathrm{x}}$ like PAN can act as a reservoir for $\mathrm{NO}_{2}$ that can be released at later times. The simplified and neglected processes are thought to counteract one another, so that our estimate should still be in the proper order of magnitude. We estimate a $\mathrm{NO}_{\mathrm{x}}$ export of $\sim 0.2 \mathrm{Gg}(\mathrm{N})$ per day. This corresponds to $\sim 50 \%$ of daily $\mathrm{NO}_{\mathrm{x}}$ emissions in the region influenced by plain-to-mountain flows (area enclosed by the thin white line in Fig. 1). The annual average $\mathrm{NO}_{\mathrm{x}}+\mathrm{PAN}$ export of the European ABL has been estimated at $21 \%$ of total emissions using a GCTM (Wild and Akimoto, 2001). This suggests that on fair weather days pollutant export by thermal wind systems enhances export by a factor of $\sim 2.5$ in the Alps. This enhancement, as yet unconsidered in GCTMs, will also occur within other European mountainous regions, such as the Pyrenees and Apennines.

$\mathrm{O}_{3}$ concentrations in the ABL are typically high ( $>80 \mathrm{ppbv}_{3}$ ) for the investigated weather conditions and for air masses advected from the Po Basin (Prevot et al., 1997). Heavy goods and passenger traffic through the Swiss Alps have increased by $72 \%$ and $18 \%$ in the last decade, respectively, and are expected to grow in the future. Due to enhanced $\mathrm{O}_{3}$ production efficiency 
in the FT $\left(\sim 25\left(\right.\right.$ molec. $\left.\mathrm{O}_{3}\right) /\left(\right.$ molec. $\left.\mathrm{NO}_{\mathrm{x}}\right)$ in the spring time FT above the Alps (Carpenter et al., 2000) and $\sim 5\left(\right.$ molec. $\left.\mathrm{O}_{3}\right) /\left(\right.$ molec. $\left.\mathrm{NO}_{\mathrm{x}}\right)$ in the European ABL $(\mathrm{Hov}$ and Flatoy, 1997)) and rapid vertical transport, a $\mathrm{NO}_{\mathrm{x}}$ molecule emitted in an Alpine valley and lifted to the FT might produce more $\mathrm{O}_{3}$ than a $\mathrm{NO}_{\mathrm{x}}$ molecule above flat terrain. Therefore considerable amounts of $\mathrm{O}_{3}$ are exported directly and indirectly to the FT.

\section{Conclusions}

Topographic venting of ABL air from deep Alpine valleys to the FT was quantified from observed air mass budgets for two Alpine valleys during three aircraft campaigns. As much as 3 times the up-valley wind layer air mass is exported on a fair weather day during the summer. Observations of atmospheric backscatter ratios observed by an airborne lidar confirm this venting mechanism. Pollutants and moisture are exported from the ABL within the valley to the injection layer. This layer reaches up well above crest height to about $4000 \mathrm{~m}$ a.s.l. Our observations also suggest that, besides turbulence and large scale flow, daytime slope winds play a major role in vertical export. Pollutants trapped in the injection layer leave the mountainous terrain well above the ABL of the forelands, and therefore become part of the FT. Strong topographic venting is favored on about 50 days during the spring and summer when strong solar insolation occurs. Trajectory studies for these days show that the initial height above the Alps determines how fast and at what altitude an air mass is transported southward, exporting European air pollutants which were lifted by topographic venting above the Alps.

Topographic venting is expected to play a relatively more important role in Europe than in North America and Asia where pollutant export is influenced more strongly by warm conveyer belts (upward airflow within extratropical cyclone ahead of the cold front) that are less frequently observed in Europe (Stohl, 2001).

Since $27 \%$ of the Earth's land surface is defined as mountainous (altitude $>1500 \mathrm{~m}$ a.s.l.) (Messerli and Ives, 1997) and mountain ranges lower than the Alps tend to force thermal convection as well (Kossmann et al., 1999), topographic venting is not only of regional European but of global importance. However, complex topography is only treated on a sub-grid scale in GCTMs, consequently topographic venting is not represented properly (Noppel and Fiedler, 2002). Development of a suitable topographic venting parameterization for GCTMs will help to better quantify the effects of thermal air flow in mountainous terrain on continental and global tropospheric pollution budgets.

Investigations on a climatological scale, e.g. long term lidar studies or analysis of operationally available sounding data, could verify the significance of the topographic venting mechanism. The chemical composition of the ABL and the injection layer was analyzed during both VOTALP and CHAPOP campaigns. The gathered information will be used in a subsequent paper to quantify the expected $\mathrm{O}_{3}$ production efficiency enhancement in an air mass lifted to the injection layer.

Acknowledgements. Support by the European Commission for the projects VOTALP and CAATER is acknowledged. Ground based meteorological data and flight planing support was provided by MeteoSwiss. Special thanks go to V. Fumagalli and the Kanton Ticino for supporting the build-up of the measurement sites during the CHAPOP campaign. Measurements within the Leventina valley were also supported by the Swiss National Science Foundation (Grant No. 21-61573.00). We would also like to thank the crews of the DLR Falcon, the Meteo France MERLIN IV, the MetAir and all involved groups in both projects.

Edited by: S. Galmarini

\section{References}

Atkinson, B. W.: Meso-scale Atmospheric Circulations, Academic Press, London, 1981.

Atkinson, B. W. and Shahub, A. N.: Orographic and Stability Effects on Daytime, Valley-Side Slope Flows, Bound. Lay. Met., 68, 275-300, 1994.

Baltensperger, U., Gaggeler, H. W., Jost, D. T., Lugauer, M., Schwikowski, M., Weingartner, E., and Seibert, P.: Aerosol climatology at the high-alpine site Jungfraujoch, Switzerland, J. Geophys. Res., 102, 19707-19715, 1997.

Berkowitz, C. M., Fast, J. D., and Easter, R. C.: Boundary layer vertical exchange processes and the mass budget of ozone: Observations and model results, J. Geophys. Res., 105, 14 789-14 805, 2000.

BUWAL and UBA: Handbook Emission Factors for Road Transport, Tech. rep., Bundesamt für Umwelt und Landschaft, Schweiz Umweltbundesamt, Deutschland, 1999.

Carnuth, W. and Trickl, T.: Transport studies with the IFU threewavelength aerosol lidar during the VOTALP Mesolcina experiment, Atmos. Environ., 34, 1425-1434, 2000.

Carpenter, L. J., Green, T. J., Mills, G. P., Bauguitte, S., Penkett, S. A., Zanis, P., Schuepbach, E., Schmidtbauer, N., Monks, P. S., and Zellweger, C.: Oxidized nitrogen and ozone production efficiencies in the springtime free troposphere over the Alps, J. Geophys. Res., 105, 14 547-14 559, 2000.

Cotton, W., Alexander, G., Hertenstein, R., Walko, R., McAnelly, R., and Nicholls, M.: Cloud venting - A review and some new global annual estimates, Earth Sci. Rev., 39, 169-206, 1995.

De Wekker, S. F. J., Steyn, D. G., Fast, J. D., Rotach, M. W., and Zhong, S.: The performance of RAMS in representing the convective boundary layer structure in a very steep valley, Environ. Fluid Mech., in press, 2004a.

De Wekker, S. F. J., Steyn, D. G., and Nyeki, S.: A comparison of aerosol layer- and convective boundary layer structure over a mountain range during STAAARTE '97, Bound. Lay. Met., in press, 2004b.

Defant, F.: Zur Theorie der Handwinde, nebst Bemerkungen zur Theorie der Berg- und Talwinde (A theory of slope winds, along 
with remarks on the theory of mountain and valley winds), Arch. Met. Geoph. Biokl., Ser. A, A1, 421-450, 1949.

Egger, J., Bajrachaya, S., Egger, U., Heinrich, R., Reuder, J., Shayka, P., Wendt, H., and Wirth, V.: Diurnal winds in the Himalayan Kali Gandaki Valley. Part I: Observations, Mon. Wea. Rev., 128, 1106-1122, 2000.

Egger, J., Bajrachaya, S., Heinrich, R., Kolb, P., Lammlein, S., Mech, M., Reuder, J., Schaper, W., Shakya, P., Schween, J., and Wendt, H.: Diurnal winds in the Himalayan Kali Gandaki valley. part III: Remotely piloted aircraft soundings, Mon. Wea. Rev., 130, 2042-2058, 2002.

Fiedler, F.: Atmospheric Circulation, in Chemistry of the Unpolluted and Polluted Troposphere, edited by Georgii, H. W. and Jaeschke, W., p. 509, Reidel Publishing Company, Dordrecht, 1982.

Forrer, J., Ruttimann, R., Schneiter, D., Fischer, A., Buchmann, B., and Hofer, P.: Variability of trace gases at the high-Alpine site Jungfraujoch caused by meteorological transport processes, J. Geophys. Res., 105, 12 241-12 251, 2000.

Freytag, C.: Results from the MERKUR Experiment: Mass Budget and Vertical Motions in a Large Valley During Mountain and Valley Wind, Meteorol. Atmos. Phys., 37, 129-140, 1987.

Furger, M., Dommen, J., Graber, W., Poggio, L., Prévôt, A., Emeis, S., Grell, G., Trickl, T., Gomiscek, B., Neininger, B., and Wotawa, G.: The VOTALP Mesolcina Valley Campaign 1996 concept, background and some highlights, Atmos. Environ., 34, 1395-1412, 2000.

Hov, O. and Flatoy, F.: Convective redistribution of ozone and oxides of nitrogen in the troposphere over Europe in summer and fall, J. Atmos. Chem., 28, 319-337, 1997.

Jacob, D. J., Prather, M. J., Rasch, P. J., Shia, R. L., Balkanski, Y. J., Beagley, S. R., Bergmann, D. J., Blackshear, W. T., Brown, M., Chiba, M., Chipperfield, M. P., deGrandpre, J., Dignon, J. E., Feichter, J., Genthon, C., Grose, W. L., Kasibhatla, P. S., Kohler, I., Kritz, M. A., Law, K., Penner, J. E., Ramonet, M., Reeves, C. E., Rotman, D. A., Stockwell, D. Z., VanVelthoven, P. F. J., Verver, G., Wild, O., Yang, H., and Zimmermann, P.: Evaluation and intercomparison of global atmospheric transport models using Rn-222 and other short-lived tracers, J. Geophys. Res., 102, 5953-5970, 1997.

Kiemle, C., Kastner, M., and Ehret, G.: The Convective BoundaryLayer Structure from Lidar and Radiosonde Measurements During the Efeda-91 Campaign, J. Atmos. Ocean. Technol., 12, 771$782,1995$.

King, C. W.: Representativeness of Single Vertical Wind Profiles for Determining Volume Flux in Valleys, J. Appl. Meteorol., 28, 463-466, 1989.

Kossmann, M., Corsmeier, U., De Wekker, S., Fiedler, F., Vögtlin, R., Kalthoff, N., Güsten, H., and Neininger, B.: Observations of Handover Processes between the Atmospheric Boundary Layer and the Free Troposphere over Mountainous Terrain, Contr. Atmos. Phys., 72, 329-350, 1999.

Lelieveld, J. and Crutzen, P. J.: Role of Deep Cloud Convection in the Ozone Budget of the Troposphere, Science, 264, 1759-1761, 1994.

Lelieveld, J., Berresheim, H., Borrmann, S., Crutzen, P. J., Dentener, F. J., Fischer, H., Feichter, J., Flatau, P. J., Heland, J., Holzinger, R., Korrmann, R., Lawrence, M. G., Levin, Z., Markowicz, K. M., Mihalopoulos, N., Minikin, A., Ramanathan,
V., de Reus, M., Roelofs, G. J., Scheeren, H. A., Sciare, J., Schlager, H., Schultz, M., Siegmund, P., Steil, B., Stephanou, E. G., Stier, P., Traub, M., Warneke, C., Williams, J., and Ziereis, H.: Global air pollution crossroads over the Mediterranean, Science, 298, 794-799, 2002.

Lin, X., Trainer, M., and Liu, S. C.: On the Nonlinearity of the Tropospheric Ozone Production, J. Geophys. Res., 93, 15879 $15888,1988$.

Lugauer, M. and Winkler, P.: Alpines Pumpen - Thermische Zirkulation zwischen Alpen und bayrischem Alpenvorland "Alpine pumping - thermal circulation between the Alp and the Bavarian forelands", Tech. rep., Deutscher Wetterdienst, 2002.

McKendry, I. G. and Lundgren, J.: Tropospheric layering of ozone in regions of urbanized complex and/or coastal terrain: a review, Prog. Phys. Geogr., 24, 329-354, 2000.

Messerli, B. and Ives, J. (Eds): Mountains of the World: A Global Priority, Parthenon, New York \& London, 1997.

Millan, M. M., Sanz, M. J., Salvador, R., and Mantilla, E.: Atmospheric dynamics and ozone cycles related to nitrogen deposition in the western Mediterranean, Environ. Pollut., 118, 167-186, 2002.

Neininger, B., Fuchs, W., Baeumle, M., Volz-Thomas, A., Prévôt, A., and Dommen, J.: A small aircraft for more than just ozone: METAIR's 'DIMONA' after ten years of evolving development, in 11th Symposium on Meteorological Observations and Instrumentation, American Meteorological Society, Albuquerque, NM, USA, 2001.

Newell, R. E., Thouret, V., Cho, J. Y. N., Stoller, P., Marenco, A., and Smit, H. G.: Ubiquity of quasi-horizontal layers in the troposphere, Nature, 398, 316-319, 1999.

Noppel, H. and Fiedler, F.: Mesoscale heat transport over complex terrain by slope winds - A conceptual model and numerical simulations, Bound. Lay. Met., 104, 73-97, 2002.

Nyeki, S., Li, F., Weingartner, E., Streit, N., Colbeck, I., Gaggeler, H. W., and Baltensperger, U.: The background aerosol size distribution in the free troposphere: An analysis of the annual cycle at a high-alpine site, J. Geophys. Res., 103, 31 749-31 761, 1998.

Nyeki, S., Kalberer, M., Colbeck, I., De Wekker, S., Furger, M., Gäggeler, H., Kossmann, M., Lugauer, M., Steyn, D., Weingartner, E., Wirth, M., and Baltensperger, U.: Convective Boundary Layer Evolution to $4 \mathrm{~km}$ als over High-Alpine Terrain: Airborne Lidar Observations in the Alps, Geophys. Res. Lett., 27, 689692, 2000.

Nyeki, S., Eleftheriadis, K., Baltensperger, U., Colbeck, I., Fiebig, M., Fix, A., Kiemle, C., Lazaridis, M., and Petzold, A.: Airborne lidar and in-situ aerosol observations of an elevated layer, leeward of the European Alps and Apennines, Geophys. Res. Lett., 29, 1852, 2002.

Poggio, L. P., Furger, M., Prevot, A. S. H., Graber, W. K., and Andreas, E. L.: Scintillometer wind measurements over complex terrain, J. Atmos. Ocean. Technol., 17, 17-26, 2000.

Prevot, A. S. H., Staehelin, J., Kok, G. L., Schillawski, R. D., Neininger, B., Staffelbach, T., Neftel, A., Wernli, H., and Dommen, J.: The Milan photooxidant plume, J. Geophys. Res., 102, 23 375-23 388, 1997.

Prevot, A. S. H., Dommen, J., and Baeumle, M.: Influence of road traffic on volatile organic compound concentrations in and above a deep Alpine valley, Atmos. Environ., 34, 4719-4726, 2000.

Rucker, M.: Observational and numerical study of daytime flows 
in an Alpine valley, Phd thesis, University of British Columbia, 2003.

Seibert, P.: Schematic description of transport of polluted air from planes into the free troposphere through mountain regions., http: //www.boku.ac.at/imp/envmet/alpine_vert_exchg.html, 1996.

Seibert, P., Kromp-Kolb, H., Kasper, A., Kalina, M., Puxbaum, H., Jost, D. T., Schwikowski, M., and Baltensperger, U.: Transport of polluted boundary layer air from the Po Valley to high-alpine sites, Atmos. Environ., 32, 3953-3965, 1998.

Seibert, P., Beyrich, F., Gryning, S. E., Joffre, S., Rasmussen, A., and Tercier, P.: Review and intercomparison of operational methods for the determination of the mixing height, Atmos. Environ., 34, 1001-1027, 2000.

Seinfeld, J. H. and Pandis, S. N.: Atmospheric chemistry and physics, Wiley, New York, 1998.

Stohl, A.: A 1-year Lagrangian "climatology" of airstreams in the Northern Hemisphere troposphere and lowermost stratosphere, J. Geophys. Res., 106, 7263-7279, 2001.

Stohl, A., Wotawa, G., Seibert, P., and Kromp-Kolb, H.: Interpolation Errors in Wind Fields as a Function of Spatial and Temporal Resolution and Their Impact on Different Types of Kinematic Trajectories, J. Appl. Meteorol., 34, 2149-2165, 1995.

Stull, R. B.: An Introduction to Boundary Layer Meteorology, Kluwer Academic Publishers, Dordrecht, 1988.

Traub, M., Fischer, H., de Reus, M., Korrmann, R., Heland, J., Ziereis, H., Schlager, H., Holzinger, R., Warneke, C., de Gouw, J. A., and Lelieveld, J.: Chemical characteristics assigned to trajectory clusters during the MINOS campaign, Atmos. Chem. Phys. Discuss., 3, 107-134, 2003.
Tyson, P. D. and D'Abreton, P. C.: Transport and recirculation of aerosols off southern Africa - Macroscale plume structure, Atmos. Environ., 32, 1511-1524, 1998.

Vergeiner, I. and Dreiseitl, E.: Valley Winds and Slope Winds Observations and Elementary Thoughts, Meteorol. Atmos. Phys., 36, 264-286, 1987.

Whiteman, C. D. and Dreiseitl, E.: Alpine meteorology: Translations of classic contributions by A. Wagner, E. Ekhart and F. Defant, Tech. rep., Pacific Northwest Laboratory, 1984.

Wild, O. and Akimoto, H.: Intercontinental transport of ozone and its precursors in a three-dimensional global CTM, J. Geophys. Res., 106, 27 729-27 744, 2001.

Wotawa, G. and Kromp-Kolb, H.: The research project VOTALP general objectives and main results, Atmos. Environ., 34, 13191322, 2000.

Wotawa, G., Kroger, H., and Stohl, A.: Transport of ozone towards the Alps - results from trajectory analyses and photochemical model studies, Atmos. Environ., 34, 1367-1377, 2000.

Zangl, G., Egger, J., and Wirth, V.: Diurnal winds in the Himalayan Kali Gandaki Valley. Part II: Modeling, Mon. Wea. Rev., 129, 1062-1080, 2001.

Zellweger, C., Ammann, M., Buchmann, B., Hofer, P., Lugauer, M., Ruttimann, R., Streit, N., Weingartner, E., and Baltensperger, U.: Summertime $\mathrm{NO}_{\mathrm{y}}$ speciation at the Jungfraujoch, $3580 \mathrm{~m}$ above sea level, Switzerland, J. Geophys. Res., 105, 6655-6667, 2000. 